\title{
САХАРНЫЙ ДИАБЕТ 1 ТИПА У РЕБЕНКА С ПСЕВДОГИПОПАРАТИРЕОЗОМ
}

\author{
Кузнецова П.В., Власенко Н.Ю., Юдицкая Т.А., Павлинова Е.Б., Юнгман Н.В., Каргаполова К.И. \\ ФГБОУ ВО «Омский государственный медицинский университет» Минздрава России \\ БУзОО «Областная детская клиническая больница», г. Омск
}

Представлен клинический случай пациентки с сочетанной эндокринной патологией: псевдогипопаратиреозом, аутоиммунным тиреоидитом и сахарным диабетом 1 типа, переведенной на быстродействующий инсулин аспарт+никотинамид, что позволило улучшить гликемический контроль и тем самым улучшить прогноз течения сахарного диабета 1 типа.

ЦЕЛЬ: оценить эффективность препарата инсулин аспарт+никотинамид у пациентки с рядом сопутствующих эндокринных заболеваний по оценке времени в целевом диапазоне, количеству эпизодов гипогликемий через 3 месяца. Проанализировать динамику гликированного гемоглобина (HbA $\left.{ }_{1 c}\right)$.

МАТЕРИАЛЫ И МЕТОДЫ: под нашим наблюдением находилась пациентка 10 лет с диагнозом: Псевдогипопаратиреоз 1а: резистентность к ПТГ, наследственная остеодистрофия Олбрайта с мутацией в гене GNAS.G.40.3 (с 2-х лет). Ожирение (SDS ИMT +2,81), брахидактилия типа E. SDS роста $(-2,06)$ Сахарный диабет 1 типа без осложнений (с 6,5 лет). Хронический аутоиммунный тиреоидит, стадия медикаментозного эутиреоза. Киста правой доли щитовидной железы. Генетическая эпилепсия, с билатеральными судорожными приступами. Гиперметропия слабой степени обоих глаз. Смешанный астигматизм. Врожденный порок сердца: открытый артериальный проток, состояние после рентгенэндоваскулярной окклюзии от 15.08.2015. Нейрогенная дисфункции мочевого пузыря.

На третьем году течения СД1 значительное ухудшение гликемического контроля, отрицательная динамика по гликированному гемоглобину гем, выраженная вариабельность гликемии. В марте 2021г. была переведена с комбинации инсулина Деглюдек+Лизпро на сверхбыстрый инсулин Аспарт под контролем SGMS -мониторирования (i-Pro 2 «Medtronic»). С потребностью в базальном- инсулин Деглюдек 0,2 ЕД/кг/сут. Болюсный на 1XЕ-1 ЕД (суточная потребность 0,7 ЕД/кг/сут).

РЕзУЛЬтАТЫ: спустя 3 месяца наблюдения $\mathrm{HbA}_{1}$ с снизился с 8,5\% до 7,8\% (на 0,7\%) без изменения суточной дозы инсулина. По данным SGMS-мониторирования, время нахождения в целевом диапазоне (3,9-10,0 ммоль/л) (TIR) увеличилось с 45\% до 56\%. Вариабельность гликемии снизилась с 7 ммоль/л до 5 ммоль/л. Отмечалось снижение постпрандиальной гликемии с 11,8 до 9,9 ммоль/л. Снижение пиков постпрандиальной гликемии. Эпизодов тяжелой гипогликемии на препарате не зарегистрировано. Количество легких гипогликемий до и после назначения препарата было не более $1 \%$. Со слов девочки значительно улучшилось качество жизни - не требуется выдерживать 15 минут до постановки инсулина и уменьшилось количество позывов на мочеиспускание.

ВЫВОдЫ: быстродействующий инсулин аспарт+никотинамид - это возможность для пациентов с СД1 типа с тяжелой сочетанной эндокринной патологией эффективнее контролировать постпрандиальную гликемию и чувствовать себя увереннее и свободнее.

КЛЮЧЕВЫЕ СЛОВА: сахарный диабет 1 munа; дети; псевдогипопаратиреоз; флээ-мониторинг 